\title{
Evaluasi Jaringan Stasiun Hujan di Wilayah Sungai Dumoga Sangkub
}

\author{
Ayisya Cindy Harifa'*, Moh. Charits ${ }^{2}$, Joko Setiono ${ }^{3}$, Moch. Khamim ${ }^{4}$ \\ 1,2,3,4Jurusan Teknik Sipil, Politeknik Negeri Malang, Jl. Soekarno Hatta No.9 Kota Malang, Jawa Timur. \\ *e-mail corresponding author : ayisya.civil@polinema.ac.id
}

\begin{abstract}
ABSTRAK
Data hujan sangat sering digunakan dalam proses analisis hidrologi Analisa hidrologi memerlukan data dasar yang benar, data dasar akan berdampak besar dalam proses perencanaan dan penelitian dalam sumberdaya air, sehingga hasil yang didapat akan lebih optimum.. Sebaran pos hidrologi akan menentukan tingkat kualitas analisa hidrologi. Tujuan evaluasi jaringan adalah mengetahui sebaran dan kondisi pos hujan, sehingga akan didapatkan rekomendasi stasiun hujan yang baru, dengan sebaran yang sudah mewakili setiap daerah aliran sungai. Dalam penelitian ini Metode WMO (World Meteorological Organization) dirasa tepat untuk menggambarkan sebaran stasiun hujan. Sedangkan untuk mengevaluasi stasiun hujan eksisting menggunakan metode Kagan rodda. Berdasarkan analisa kerapatan WMO dan Peta Polygon Thiessen, Sebaran stasiun hujan di wilayan sungai Dumoga Sangkub sudah cukup merata, akan tetapi belum mewakili setiap Daerah Aliran Sungai (DAS). Hasil analisa Kagan Rodda menyatakan hanya 7 stasiun hujan yang memenuhi kriteria kagan, yaitu stasiun Pusian, Toraut, Andigile Buko, Bolangitan - Paku, Lolak - Solog, Moayat, Buyat - Buyat. Hasil analisa kagan juga merekomendasikan 19 titik stasiun baru yang tersebar diseluruh Wilayah Sungai.
\end{abstract}

Kata Kunci : kerapatan pos hujan; hujan; kagan rodda

\begin{abstract}
Rainfall data always use in analytical process. Hydrology analysis need correct base data, base data will give impact to the planning and research processes in water resources, and the result will be optimum. The quality and basic data that will be used for an analysis is very dependent on the distribution of existing bydrological posts in monitoring hydrological characteristics accurately and correctly. The purpose of network evaluation is to reach the distribution and condition of rain stations, so that a new rain station recommendation will be obtained, with distributions that already represent each watershed. Rain station distribution analysis uses the WMO (World Meteorological Organization) method, to evaluate the existing rain station using the Kagan rodda method. According to the analysis of WMO density and Polygon Thiessen Map, the distribution of the rain stations in the Dumoga Sangkub river area is quite evenly distributed, but does not yet represent each $W$ atershed. The results of the Kagan Rodda analysis stated that only 7 rain stations met the kagan criteria, i.e: Pusian, Toraut, Andigile Buko, Bolangitan - Paku, Lolak - Solog, Moayat, Buyat - Buyat. The results of the kagan analysis also recommend 19 new station points through each watershed.
\end{abstract}

\section{Keywords : rain gauge density; rainfall; kagan rodda}

Cara Mengutip : Harifa, A. C., Charits, M., Setiono, J., Khamim, M. (2020). Evaluasi Jaringan Stasiun Hujan di Wilayah Sungai Dumoga Sangkub. Reka Buana : Jurnal Ilmiah Teknik Sipil dan Teknik Kimia, 5(1), 37-50. http://dx.doi.org/10.33366/rekabuana.v5i1.1607 


\section{PENDAHULUAN}

Sebuah analisa hidrologi dalam pengembangan sumber daya air, dipengaruhi data-data hidrometerologi seperti, data hujan, temperature, kecepatan angin, debit sungai, dan data iklim lainnya. Data dasar hidrologi tersebut sangat penting sebagai masukan dalam menghitung analisis hidrologi bagi suatu pengembangan, penelitian dan pengelolaan sumber daya air.

Penelitian hidrologi memiliki kegunaan lebih lanjut bagi teknik lingkungan, kebijakan lingkungan, serta perencanaan. Hidrologi juga mempelajari perilaku hujan terutama meliputi periode ulang curah hujan, karena berkaitan dengan perhitungan banjir serta rencana untuk setiap bangunan teknik sipil antara lain bendung, bendungan dan jembatan.[1]

Analisis Hidrologi tersebut terdiri dari analisis ketersediaan air, banjir rencana, aliran rendah, sedimentasi, dan pola operasi waduk. Eperti yang dikatakan oleh Ranesa, Lalu yaitu "Sebagaimana yang tertuang pada Undang undang Sumber Daya Air no.7 Tahun 2004 tentang ketersediaan data dan informasi hidrologi yang memadai, akurat, tepat waktu dan berkesinambungan, maka perlu adanya analisis untuk mengetahui apakah jumlah pos hujan yang ada saat ini dapat mewakili kondisi wilayah lokasi studi sehingga dapat mengoptimumkan jumlah pos yang juga bertujuan untuk menjadi kebijakan untuk pengambil keputusan bagi instansi terkait untuk efisiensi biaya, tenaga peralatan dan waktu, maka perlu rasionalisasi jaringan pos hujan yang optimal dan efisien baik dari segi ekonomis maupun pengelolaan sehingga secara dini dapat diketahui pos-pos mana yang sangat dominan"'[2, p. 46]
Dalam penelitiannya Fathoni, Syarif mengatakan bahwa "Kesalahan dalam pemantauan data dasar hidrologi dalam suatu daerah aliran sungai akan menghasilkan data yang tidak akurat" [3, p. 126]. Sehingga dapat dikatakan bahwa data yang salah akan menghasilkan hasil yang salah pula. Sehingga data dasar dalam proses analisis hidrologi harus dipantau dengan baik dan oleh sumber daya yang cakap, dan nantinya akan menghasilkan sebuah hasil yang akurat yang tepat guna.

Kualitas dan data dasar yang akan digunakan untuk suatu analisis sangat tergantung pada seberapa jauh pos hidrologi yang ada dalam memantau karakteristik hidrologi dalam suatu daerah aliran sungai tersebut atau dengan kata lain berapa jumlah pos hidrologi dan dimana lokasinya yang perlu ditempatkan dalam suatu DAS untuk memantau karakteristik hidrologi secara akurat dan benar. Sebaran pos hidrologi akan sangat berpengaruh pada kulaitas dari data dasar yang dihasilkan. Stasiun hujan yang ditempatkan di lokasi yang tepat dapat menggambarkan karakteristik hidrologi DAS dengan tepat.

Pada Wilayah Sungai Dumoga Sangkub, jumlah stasiun hujan yang sudah beroprasi sudah cukup memenuhi, akan tetapi sebaran peletakan pos hujan tersebut tidak memenuhi syarat dari kerapatan pos hujan yang sudah diataur oleh WMO. Sehingga keterwakilan pos hujan dari setiap DAS yang terdapat pada WS Dumoga Sangkub tersebut tidak memenuhi. Terdapat banyak DAS yang tidak memiliki pos hujan. Berdasarkan latar belakang kondisi stasiun hujan tersebut, sehingga kebutuhan analisa untuk penataan pos hujan yang dapat menghasilkan pos hujan efektif, efisien, dan dapat menggambarkan 
kondisi hidrologi pada wilayah tersebut, sangat diperlukan.

Dalam hal ini peneliti melakukan analisa mengenai kerapatan stasiun hujan di wilayah sungai dumoga sangkub dengan mempertimbangan kondisi existing di wilayah studi, berupa lokasi stasiun hidrologi dan jumlah.

Sebagai upaya membatasi ruang lingkup yang meluas, maka peneliti memberikan batasan dan menitikberatkan penelitian dalam beberapa hal sebagai berikut : Penelitian menggunakan metode Kagan Rodda, dilakukan hanya pada stasiun hujan exsisting di seluruh WS Dumoga Sangkub, data hujan yang digunakan adalah data hujan tahun 2008 hingga 2014.

Tujuan dari penelitian ini adalah mengetahui sebaran pos hujan di WS Dumoga Sangkub, mengetahui kondisi pos hujan eksisting dan kesesuaian dengan pedoman kerapatan pos hidrologi, serta merekomendasikan jaringan stasiun hujan baru.

Manfaat dari penelitian ini adalah sebagai rujukan untuk penempatan pos hujan baru, dan pemindahan pos hujan eksisting.

\section{METODE PENELITIAN}

\subsection{Lokasi}

Wilayah Sungai Dumoga Sangkub secara astronomi WS Dumoga Sangkub terletak antara $0.292-1.005$ Lintang Utara dan 123.060 - 124.736 Bujur Timur. Dan secara administratif berada di wilayah tujuh Kabupaten/Kota, yaitu:

1. Kab. Gorontalo Utara 32484,5 Ha.

2. Kotamubagu 3745,94 Ha.

3. Bolaan Mongondow Selatan 161011.22 Ha.

4. Bolaan Mongondow Utara 106534.94 Ha.

5. Bolaan Mongondow 336317.13 Ha.

6. Minahasa Selatan 24286.56 Ha.

7. Bolaan Mongondow Timur 80518.97 Ha.

\subsection{Data}

Data-data yang dibutuhkan pada penelitian ini adalah:

1. Data peta, berupa peta Daerah Aliran Sungai, Peta lokasi pos hujan, dan Peta Administrasi.

2. Data hujan, data yang dibutuhkan adalah data hujan tahun 2008 hingga 2014, yang berada di wilayah WS Dumoga Sangkub.

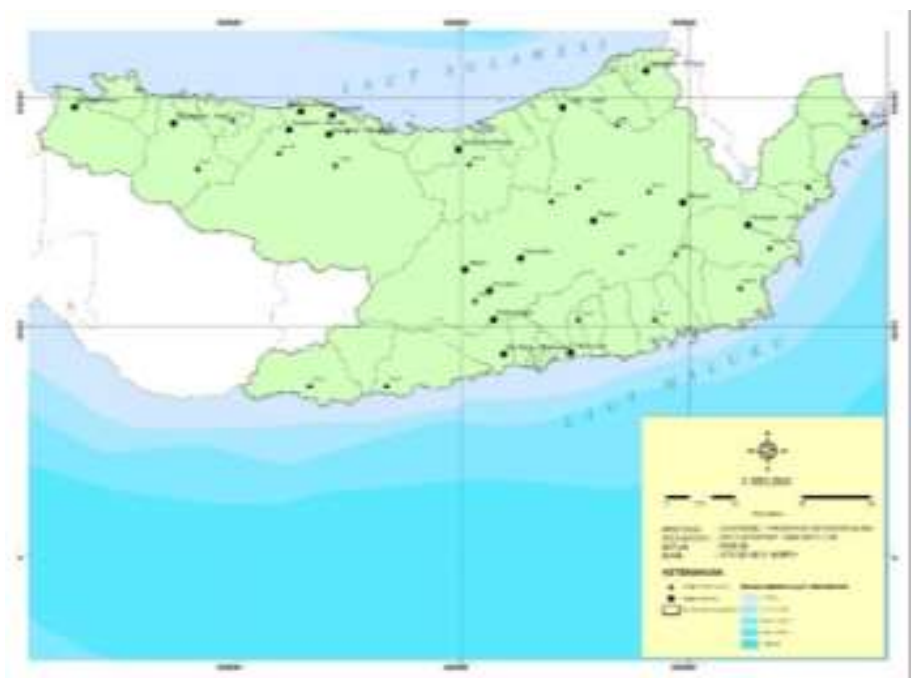

Gambar 1. Sebaran pos hujan 


\subsection{Analisa Kerapatan Jaringan}

Desain jaringan pos hujan merupakan kegiatan penting yang harus dilakukan karena data yang akan diperoleh merupakan input pada sistem DAS. Jaringan pos hujan diperlukan karena input hujan dalam sistem DAS adalah tidak beraturan dalam ruang dan waktu. Hujan wilayah (areal rainfald) diperlukan untuk mengetahui jumlah air hujan yang ada di seluruh DAS (secara merata) dan yang pada akhirnya akan menuju ke sistem drainasi DAS.

Hujan yang turun umumnya merupan hujan yang terjadi pada satu wilayah, nilai dari hujan yang jatuh diwakili oleh satu titik pada stasiun hujan, sehingga peletakan stasiun hujan akan memperhatikan banyak faktor, seperti topografi, penutupan lahan, ekonomi, dsb. Kerapatan yang disarankan oleh WMO pada suatu area, yang dapat diaplikasikan di lokasi studi adalah sebagai berikut $[4$, p. 24] :

Tabel 1. Minimum Kerapatan jaringan

\begin{tabular}{lcc}
\multicolumn{2}{c}{ Pos Hujan $\left(\mathbf{k m}^{2} / \mathbf{p o s}\right)$} \\
\hline $\begin{array}{c}\text { Physiographic } \\
\text { Unit }\end{array}$ & \multicolumn{2}{c}{ Precipittaion } \\
\cline { 2 - 3 } & $\begin{array}{c}\text { Non } \\
\text { Recording }\end{array}$ & Recording \\
\hline Coastal & 900 & 9000 \\
\hline Moutain & 250 & 2500 \\
\hline Interio Plains & 575 & 5750 \\
\hline Hilly/Undulating & 575 & 5750 \\
\hline Small Island & 25 & 250 \\
\hline Urban Areas & - & $20-10$ \\
\hline Polar/Arid & 10000 & 10000 \\
\hline
\end{tabular}

Membuat polygon thiessen dengan tahapan sebagai berikut:

1. Menggambarkan lokasi stasiun hujan pada peta lokasi penelitian.

2. Poin-pion yang menggambarkan lokasi pos dihubungkan dengan garis yang akan membentuk segitiga;
3. Menentukan garis berat yang terdapat pada segitiga, sehingga membentuk sebuah polygon yang mengeilingi stasiun. Stasiun hujan mewakili daerah yang terbentuk akibat polygon tersebut.

4. Besar hujan yang terjadi pada area tersebut adalah perkalian antara hujan yang tercatat dengan luas polygon yang terbentuk.

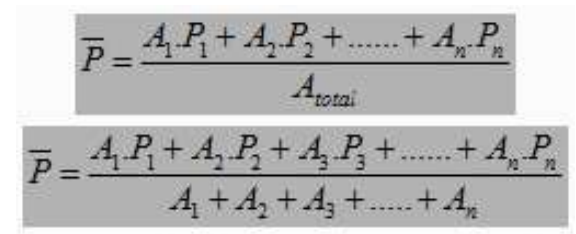

Keterangan :

$P=$ curah hujan rata-rata,

$P 1, \ldots, P n=$ curah hujan pada setiap stasiun, $A 1, \ldots, A n=$ luas yang dibatasi tiap poligon.

\subsection{Evaluasi Jaringan Stasiun Hujan}

Menentuka sebaran stasiun hujan dapat dilakukan dengan metode sederhana Kagan Rodda. Keunggulan metode ini adalah menghasilkan output berupa jumlah stasiun yang diperlukan beserta lokasinya (sebaran stasiun hujan). Cara ini dikemukakan oleh Kagan (1967). Dasar dari teori ini adalah teori stastistik, yaitu menentukan kesalahan dalam interpolasi dan perataan suatu bilangan.

Persamaan-persamaan yang digunakan dalam metode Kagan Rodda adalah sebagai berikut [5]:

$$
\begin{aligned}
& R_{(d)}=R_{(o)} e^{-d / d(o)} \\
& Z_{1}=C v \sqrt{\left[1-r_{(o)}+(0,23 \sqrt{A}) / d_{(o)} \sqrt{n}\right] / n} \\
& Z_{2}=C v \sqrt{\left(1-r_{(o)}\right) / 3+0,25 r_{(o)} / d_{(o)} \sqrt{A / n}} \\
& L=1,07 \sqrt{A / n}
\end{aligned}
$$


Keterangan:

$$
\begin{aligned}
\mathrm{r}(\mathrm{d})= & \text { koefisien korelasi dari jarak } \mathrm{d} \\
\mathrm{r}(\mathrm{O})= & \text { koefisien korelasi antara } \\
& \text { setasiun dengan jarak yang } \\
& \text { sangat kecil }( \pm 0 \mathrm{~km}) \\
\mathrm{Cv}= & \text { jarak antara setasiun, } \mathrm{km} \\
\mathrm{d}= & \text { radius korelasi, korelasi jarak } \\
& \text { stasiun dalam sistem } \\
\mathrm{A}= & \text { Luas DAS }\left(\mathrm{Km}^{2}\right) \\
\mathrm{N}= & \text { jumlah pos. } \\
\mathrm{Z1}= & \text { Kekeliruan dalam perataan }(\%) \\
\mathrm{Z} 2= & \text { Kesalahan dalam interpolasi } \\
& (\%) \\
\mathrm{L}= & \text { jarak antar pos }
\end{aligned}
$$

Untuk melakukan evaluasi dengan metode Kagan Rodda maka tahapan yang harus dilaksanakan adalah sebagi berikut:

a) Menghitung jarak antar stasiun hujan.

b) Menghitung koefisien korelasi berdasarkan data hujan bulanan.

c) Berdasarkan hasil perhitungan poin (a) dan poin (b) dilakukan penggambaran grafik hubungan korelasi dan jarak antar stasiun.

d) Penentuan nilai $r(0)$ dan $d(0)$.

e) Perhitungan curah hujan rerata daerah menggunakan metode Thiesen.

f) Menentukan standard deviasi.

g) Menghitung nilai koefisien variasi berdasarkan standart deviasi dan rerata.

h) Parameter Z1 dan Z3 dapat dihitung setelah menentukan besarnya tingkat ketelitian yang digunakan.

i) Menentukan stasiun pada suatu DAS atau area

j) Menghitung jarak setiap stasiun,

k) Menggambar jaringan segitiga sama sisi dengan panjang sisi sama dengan L seperti pada contoh Gambar di bawah ini.

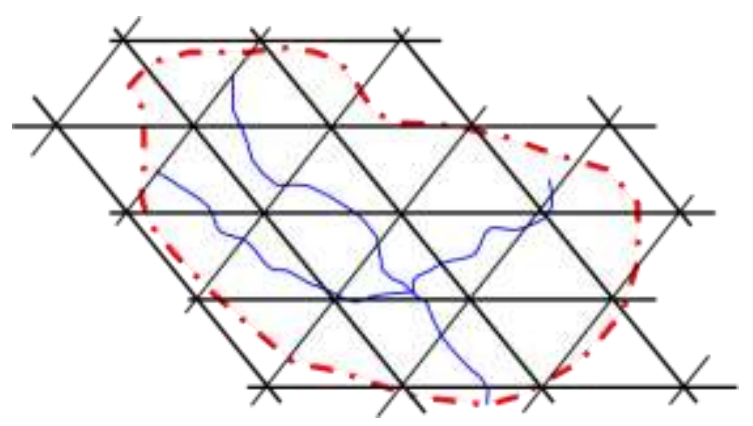

\section{Gambar 2. Jaringan Segitiga Kagan}

Metode Kagan-Rodda ini bisa dipergunakan untuk dua kondisi yaitu[6]:

1. Apabila di dalam DAS sama sekali belum ada stasiun hujan, maka cara yang dapat ditempuh adalah dengan mencoba memanfaatkan data hujan di daerah sekitarnya untuk dapat mengetahui tingkat variabilitasnya (nilai koefisien variasi) dan setelah beberapa tahun pengoperasian, maka jaringan tersebut perlu diuji kembali untuk meningkatkan kualitasnya.

2. Apabila di dalam DAS telah tersedia jaringan stasiun hujan, maka cara ini dapat dipergunakan untuk mengevaluasi apakah jaringan yang telah ada telah mencakupi (untuk tingkat ketelitian yang dikehendaki), atau dapat pula digunakan untuk menentukan pos-pos yang digunakan pada analisa berikutnya. Dalam kaitan ini jaringan yang tersedia dibandingkan dengan jaringan yang telah diperoleh dengan metode Kagan-Rodda. Jika jumlah stasiun yang telah ada masih lebih kecil dibandingkan dengan jumlah stasiun yang dituntut dengan cara KaganRodda dapat dipergunakan dengan menambahkan stasiun-stasiun yang lain. Akan tetapi apabila jumlah pos yang telah ada lebih besar dibandingkan dengan jumlah pos yang dituntut berdasarkan metode Kagan-Rodda, maka stasiunstasiun tertentu dapat tidak dipergunakan untuk analisis selanjutnya. 


\section{HASIL DAN PEMBAHASAN}

\subsection{Analisa Data}

Dalam sebuah sistem DAS jumlah komulatif dari hujan yang turun adalah input utama, yang berpengaruh besar terhadap analisa hidrologi dalam penelitian atau perencanaan. Sehingga pengukuran harus dilakukan secara cermat dan teliti.

Tabel 2. Data Asli Curah Hujan Bulanan Stasiun Pinolosian

\begin{tabular}{|c|c|c|c|c|c|c|c|c|}
\hline \multirow{2}{*}{ Bulan } & \multicolumn{8}{|c|}{ Curah Hujan (mm) } \\
\hline & 2008 & 2009 & 2010 & 2011 & 2012 & 2013 & 2014 & Average \\
\hline Januari & & & 110.50 & 145.20 & 162.20 & & 180.00 & 149.48 \\
\hline Februari & & & 44.30 & 63.10 & 104.80 & & 57.00 & 67.30 \\
\hline Maret & & & 182.50 & 127.90 & 75.40 & & 104.50 & 122.58 \\
\hline April & & & 199.30 & 178.30 & 41.00 & & 80.00 & 124.65 \\
\hline Mei & & & 168.60 & 0.00 & 394.40 & & 297.00 & 215.00 \\
\hline Juni & & & 275.40 & 0.00 & 502.30 & & 547.00 & 331.18 \\
\hline Juli & & & 425.50 & 40.70 & 795.80 & & 297.00 & 389.75 \\
\hline Agustus & & & 425.80 & 123.30 & 240.00 & & 659.00 & 362.03 \\
\hline September & & & 147.80 & 0.00 & 124.50 & & 7.00 & 69.83 \\
\hline Oktober & & & 95.00 & 0.00 & 27.00 & & 40.00 & 40.50 \\
\hline November & & & 53.00 & 86.20 & 20.00 & & 96.00 & 63.80 \\
\hline Desember & & & 125.50 & 0.00 & 185.40 & & 173.00 & 120.98 \\
\hline Jumlah & & & 2253.20 & 764.70 & 2672.80 & & 2537.50 & 2057.05 \\
\hline Rerata & & & 187.77 & 63.73 & 222.73 & & 211.46 & 171.42 \\
\hline Maksimum & & & 425.80 & 178.30 & 795.80 & & 659.00 & 389.75 \\
\hline
\end{tabular}

Data hujan yang digunakan yang digunakan dalam analisa rasionalisasi ini adalah data dari 19 pos hujan yang tersebar di seluruh wilayah sungai Dumoga Sangkub. Seperti terlihat pada tabel 2 diatas, masih terdapat tahun-tahun dengan data hujan yang tidak terekam. Banyak faktor yang menyebabkan data terekam, seperti kerusakan pada alat, alat dicuri, dsb. Untuk mengatasi kekosongan data-data tersebut dilakukan analisa pengisian data kosong dengan menggunakan metode 'Reciprocal method dinilai mempunyai unjuk-kerja yang lebih baik, karena telah memasukkan jarak antar stasiun sebagai faktor pembobot.

Menurut Bambang (2009), cara Reciprocal Method merupakan cara yang lebih baik dari metode perbandingan normal (normal ratio method) karena mempertimbangkan jarak antar stasiun. Berikut ini persamaan umum dari Reciprocal Method[7].

$$
P_{x}=\frac{\frac{P_{A}}{d_{X A}^{2}}+\frac{P_{B}}{d_{X B}^{2}}+\cdots+\frac{P_{n}}{d_{X n}^{2}}}{\frac{1}{d_{X A}^{2}}+\frac{1}{d_{X B}^{2}}+\cdots+\frac{1}{d_{X n}^{2}}}
$$

dengan:

PA, PB, ....., Pn : Hujan di stasiun A, $\mathrm{B}, \ldots \ldots ., \mathrm{n}(\mathrm{mm})$

$\mathrm{d}_{\mathrm{XA}}^{2}, \mathrm{~d}_{\mathrm{XB}}^{2}, \ldots \ldots . . \mathrm{d}_{\mathrm{XN}}^{2} \quad$ :jarak antara setasiun A dan setasiun $\mathrm{X}(\mathrm{Km})$.

hasil dari analisa pengisian data hujan yang kosong di setiap hujan menghasilkan tabel 3 dibawah ini.

Sedangkan tabel 4 adalah hasil rekapitulasi analisa hujan dari keseluruhan stasiun hujan yang terdapat di wilayah sungai Dumoga Sangkub. 
Table 3. Curah Hujan Bulanan Stasiun Pinolosian Hasil Analisa dengan Metode Pengisian Hujan yang Hilang

\begin{tabular}{lcccccccc}
\hline \multirow{2}{*}{ Bulan } & \multicolumn{7}{c}{ Curah Hujan (mm) } \\
\cline { 2 - 9 } & $\mathbf{2 0 0 8}$ & $\mathbf{2 0 0 9}$ & $\mathbf{2 0 1 0}$ & $\mathbf{2 0 1 1}$ & $\mathbf{2 0 1 2}$ & $\mathbf{2 0 1 3}$ & $\mathbf{2 0 1 4}$ & Average \\
\hline Januari & 109.53 & 174.46 & 110.50 & 145.20 & 162.20 & 125.17 & 180.00 & 143.87 \\
\hline Februari & 152.52 & 163.74 & 44.30 & 63.10 & 104.80 & 123.21 & 57.00 & 101.24 \\
\hline Maret & 195.75 & 136.16 & 182.50 & 127.90 & 75.40 & 160.53 & 104.50 & 140.39 \\
\hline April & 236.71 & 160.61 & 199.30 & 178.30 & 41.00 & 159.20 & 80.00 & 150.73 \\
\hline Mei & 282.33 & 200.98 & 168.60 & 0.00 & 394.40 & 261.92 & 297.00 & 229.32 \\
\hline Juni & 243.54 & 187.84 & 275.40 & 0.00 & 502.30 & 137.37 & 547.00 & 270.49 \\
\hline Juli & 491.08 & 126.05 & 425.50 & 40.70 & 795.80 & 402.40 & 297.00 & 368.36 \\
\hline Agustus & 450.44 & 127.19 & 425.80 & 123.30 & 240.00 & 487.32 & 659.00 & 359.01 \\
\hline September & 197.00 & 12.87 & 147.80 & 0.00 & 124.50 & 444.05 & 7.00 & 133.32 \\
\hline Oktober & 167.57 & 49.72 & 95.00 & 0.00 & 27.00 & 100.28 & 40.00 & 68.51 \\
\hline November & 161.78 & 151.80 & 53.00 & 86.20 & 20.00 & 246.36 & 96.00 & 116.45 \\
\hline Desember & 156.46 & 164.13 & 125.50 & 0.00 & 185.40 & 217.85 & 173.00 & 146.05 \\
\hline Jumlah & 2844.72 & 1655.55 & 2253.20 & 764.70 & 2672.80 & 2865.66 & 2537.50 & 2227.73 \\
\hline Rerata & 237.06 & 137.96 & 187.77 & 63.73 & 222.73 & 238.81 & 211.46 & 185.64 \\
\hline Maksimum & 491.08 & 200.98 & 425.80 & 178.30 & 795.80 & 487.32 & 659.00 & 368.36 \\
\hline & & & & & & & & \\
\hline
\end{tabular}

Tabel 4. Rekapitulasi Curah Hujan Tahunan WS Dumoga Sangkub

\begin{tabular}{|c|c|c|c|c|c|c|c|c|c|}
\hline No. & Pos Hujan & 2008 & 2009 & 2010 & 2011 & 2012 & 2013 & 2014 & AVRG \\
\hline 1 & Pinolosian & 2844.72 & 1655.55 & 2253.20 & 764.70 & 2672.80 & 2865.66 & 2537.50 & 2227.734 \\
\hline 2 & Molibagu - Bolangaso & 2596.60 & 1236.00 & 2309.00 & 4256.50 & 2348.90 & 2086.50 & 1715.00 & 2364.071 \\
\hline 3 & Matayangan & 3790.90 & 2181.00 & 2636.40 & 4920.60 & 2360.02 & 3821.90 & 2359.20 & 3152.860 \\
\hline 4 & Pusian & 2466.70 & 1997.50 & 1422.40 & 3222.40 & 1944.10 & 2160.89 & 1780.05 & 2142.006 \\
\hline 5 & Toraut & 1955.50 & 1569.80 & 2342.90 & 1734.06 & 2241.95 & 2147.70 & 1542.90 & 1933.544 \\
\hline 6 & Konarom Barat & 1943.30 & 1869.90 & 1460.20 & 2352.50 & 1970.60 & 3295.40 & 1802.95 & 2099.264 \\
\hline 7 & Andigile Buko & 1538.70 & 1675.97 & 1512.10 & 1638.70 & 891.00 & 629.90 & 773.00 & 1237.053 \\
\hline 8 & Bolangitan - Paku & 1785.90 & 1309.90 & 1689.16 & 1704.70 & 1592.30 & 1966.70 & 1721.80 & 1681.494 \\
\hline 9 & Sangkub - Huntuk & 1219.70 & 1331.60 & 1108.30 & 2425.30 & 2644.50 & 2327.60 & 1369.20 & 1775.172 \\
\hline 10 & Bintauna Pantai & 2186.00 & 1262.20 & 3130.15 & 2510.90 & 2432.20 & 2678.90 & 1755.10 & 2279.350 \\
\hline 11 & Sangkub - Pangkusa & 1370.10 & 1297.90 & 2269.10 & 2246.70 & 1858.30 & 2248.93 & 1474.50 & 1823.647 \\
\hline 12 & Ayong Bumbung & 3314.10 & 1802.70 & 2348.90 & 2189.80 & 1998.60 & 1936.30 & 1187.60 & 2111.143 \\
\hline 13 & Nonapan - Wineru & 839.66 & 689.20 & 1146.70 & 1167.00 & 1046.20 & 1163.70 & 915.80 & 995.466 \\
\hline 14 & Lolak - Solog & 1531.00 & 1209.30 & 1546.00 & 1567.00 & 1114.00 & 1402.00 & 1114.00 & 1354.757 \\
\hline 15 & Moayat & 2488.10 & 1331.50 & 924.60 & 1358.80 & 1445.10 & 1090.20 & 916.70 & 1365.000 \\
\hline 16 & Nuangan - Lanut & 2239.50 & 1944.50 & 2704.50 & 2308.00 & 2192.50 & 2181.00 & 1970.00 & 2220.000 \\
\hline 17 & Buyat - Buyat & 2353.98 & 1755.56 & 2125.70 & 1965.60 & 1770.10 & 1820.60 & 1228.60 & 1860.020 \\
\hline 18 & Klimat Doloduo I & 3093.54 & 733.80 & 2165.00 & 2724.50 & 2478.91 & 2053.20 & 1943.70 & 2170.379 \\
\hline 19 & Klimat Sangkub & 2126.63 & 1306.60 & 1406.30 & 1584.06 & 1413.54 & 1326.68 & 614.44 & 1396.894 \\
\hline
\end{tabular}




\subsection{Analisa Kerapatan Pos Hujan}

Dalam pengembangan pola sebaran hujan di masing-masing negara tidak akan pernah sama. Karena kriteria yang menjadi dasar digunakan tidak sama. Sampai saat ini belum dijumpai kriteria yang jelas dan berlaku umum untuk menetapkan kerapatan jaringan pengamatan suatu daerah. Terlebih pemakaiannya di Indonesia memerlukan kecermatan karena masih banyak masalah yang belum dapat dijelaskan. [8]

Analisa kerapatan stasiun hujan berdasarkan standar WMO (World Meteorological Organization), didasarkan pada luasan daerah pengaruh masing-masing. Luas daerah pengaruh setiap stasiun hujan menggunakan metode Poligon Thieesen.

Metode polygon thiessen dikenal juga dengan metode rata-rata timbang (weighted mean). Metode ini memberikan proporsi luasan daerah pengaruh pos penakar hujan untuk mengakomodasi ketidakseragaman jarak pos hujan.[9]
Daerah pengaruh dibentuk dengan menggambarkan garis-garis sumbu tegak lurus terhadap garis penghubung antara dua pos penakar hujan tersekat. Hasil metode thiessen lebih akurat dibandingkan dengan metode yang lain.

Prosedur penerapan metode thiessen ini meliputi beberapa langkah antara lain[10] Poligon tersebut akan memberikan data yang akurat mengenai luas daerah pengaruh dari sebuah stasiun hujan. Tabel luas daerah polygon ditampilkan pada table 5 .

Berdasarkan luas Polygon Thiessen dapat dinyatakan kerapatan stasiun hujan sudah cukup baik, yaitu pada kondisi normal $575-5750 \mathrm{~km}^{2}$ setiap stasiun. Akan tetapi, kerapatan stasiun hujan yang ada di Wilayah Sungai Dumoga Sangkub ini, belum mewakili setiap Daerah Aliran Sungai (DAS), masih terdapat DAS yang tidak memiliki pos hujan, seperti yng ditampilkan dalam gambar 1. Terlihat tidak semua DAS memiliki Pos Hujan.

Tabel 5 Luas Daerah Pengaruh Polygon Thiessen

\begin{tabular}{clcc}
\hline No & \multicolumn{1}{c}{ Stasiun } & $\begin{array}{c}\text { Luas Daerah } \\
\text { Pengaruh } \\
\left(\mathbf{k m}^{\mathbf{2}} \mathbf{)}\right.\end{array}$ & $\begin{array}{c}\text { Koefisien } \\
\text { Thiessen } \\
\mathbf{( \% )}\end{array}$ \\
\hline 1 & pinolosian & 389.79 & 0.052 \\
\hline 2 & molibagu-bolangaso & 297.74 & 0.040 \\
\hline 3 & matayangan & 285.48 & 0.038 \\
\hline 4 & pusian & 557.60 & 0.075 \\
\hline 5 & toraut & 899.54 & 0.121 \\
\hline 6 & konarom barat & 328.03 & 0.044 \\
\hline 7 & andigile-buko & 273.81 & 0.037 \\
\hline 8 & Bolangitang-Paku & 684.96 & 0.092 \\
\hline 9 & sangkub-huntuk & 73.25 & 0.010 \\
\hline 10 & bintauna pantai & 229.57 & 0.031 \\
\hline 11 & sangkub-pangkusa & 735.04 & 0.099 \\
\hline 12 & ayong bumbung & 431.32 & 0.058 \\
\hline 13 & nonapan-wineru & 289.47 & 0.039 \\
\hline 14 & lolak-solog & 371.72 & 0.050 \\
\hline 15 & Moayat & 551.08 & 0.074 \\
\hline 16 & nuangan-lanut & 656.93 & 0.088 \\
\hline 17 & buyat-buyat & 269.48 & 0.036 \\
\hline 18 & doloduo I & 82.67 & 0.011 \\
\hline 19 & sangkub & 47.42 & 0.006 \\
\hline & Jumlah & 7454.89 & 1.000 \\
\hline & & & \\
\hline
\end{tabular}




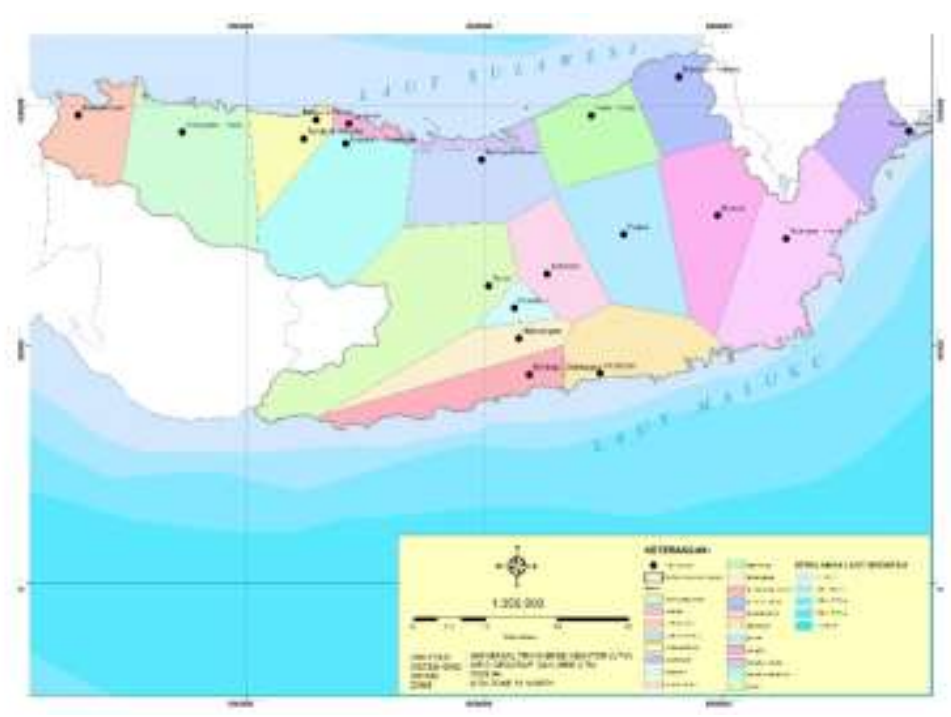

Gambar 3. polygon thiessen

Gambar 3 menunjukkan area yang stasiun hujan. Berdasarkan area itu lah yang membatasi daerah pengaruh dari setiap menunjukkan kerapatan di sebuah wilayah sungai

\subsection{Analisa Jaringan Kagan}

Pada analisa ini, dilakukan perhitungan jarak dari stasiun hujan dan menghitung koefisien korelasi jarak dari setiap stasiun.

Tabel 6 Jarak dan Korelasi Antar Stasiun

\begin{tabular}{|c|c|c|}
\hline No. & Jarak & Koefisien Korelasi Tertinggi \\
\hline 1 & 22.43 & 0.532 \\
\hline 2 & 7.91 & 0.817 \\
\hline 3 & 6.41 & 0.607 \\
\hline 4 & 34.02 & 0.556 \\
\hline 5 & 49.41 & 0.514 \\
\hline 6 & 50.54 & 0.379 \\
\hline 7 & 22.09 & 0.514 \\
\hline 8 & 104.58 & 0.640 \\
\hline 9 & 4.78 & 0.617 \\
\hline 10 & 57.58 & 0.621 \\
\hline 11 & 4.29 & 0.629 \\
\hline 12 & 24.68 & 0.708 \\
\hline 13 & 20.06 & 0.643 \\
\hline 14 & 50.72 & 0.554 \\
\hline 15 & 43.66 & 0.621 \\
\hline 16 & 34.12 & 0.574 \\
\hline 17 & 117.10 & 0.379 \\
\hline 18 & 51.89 & 0.120 \\
\hline & & \\
\hline
\end{tabular}


Selanjutnya dilakukan pembuatan dan koefisien korelasi seperti yang dapat grafik hubungan antara jarak antar stasiun dilihat pada gambar berikut:

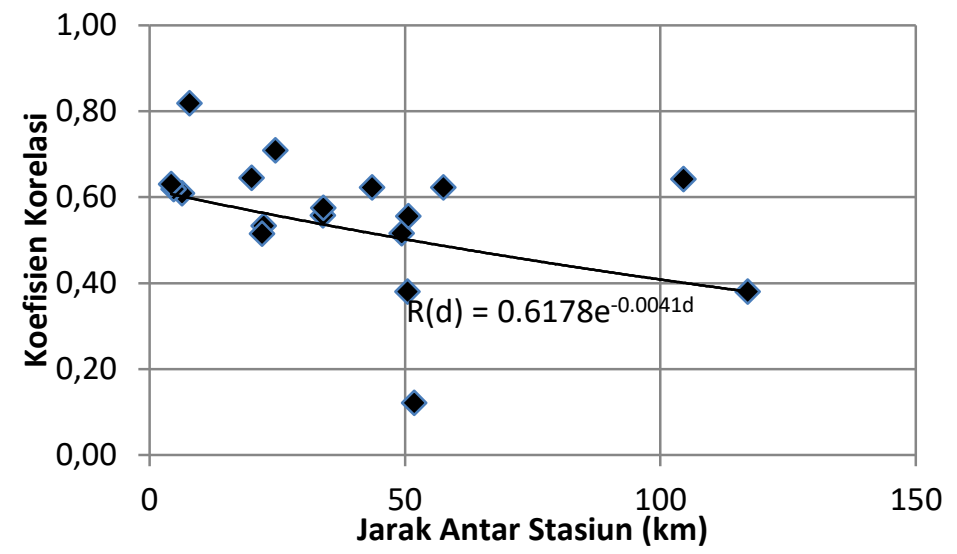

Gambar 4. Grafik Hubungan Jarak Setiap Stasiun dan Koefisien Korelasi dari Jarak Stasiun

Berdasarkan Gambar 4, didapat-kan persamaan eksponensial sebagai berikut :

$$
\mathrm{R}(\mathrm{d})=0.6178 \mathrm{e}^{-0.0041 \mathrm{~d}}
$$

Persamaan eksponensial tersebut menghasilkan parameter Kagan, yaitu $\mathrm{R}(0)$ sebesar 0.6178 dan $\mathrm{d}(0)$ sebesar 243,9 $\mathrm{Km}$.
Selanjutnya dilakukan kajian hujan rerata untuk mendapatkan nilai $\mathrm{Cv}$. Kajian hujan rerata dilakukan dengan menggunakan Metode Poligon Thiessen. Table 6 berikut ini menampilkan hasil perhitungan hujan rerata dengan metode Thiessen.

Tabel 7. Hujan Rerata

\begin{tabular}{|c|c|c|c|c|c|c|c|c|}
\hline \multirow{2}{*}{ No. } & \multirow{2}{*}{ Stasiun } & \multicolumn{7}{|c|}{ Tahun } \\
\hline & & 2008 & 2009 & 2010 & 2011 & 2012 & 2013 & 2014 \\
\hline 1 & Pinolosian & 25.68 & 10.51 & 22.26 & 9.32 & 41.61 & 25.48 & 34.46 \\
\hline 2 & Molibagu - Bolangaso & 21.36 & 7.77 & 26.32 & 64.42 & 30.39 & 16.22 & 18.25 \\
\hline 3 & Matayangan & 26.74 & 12.37 & 20.22 & 44.31 & 23.36 & 27.48 & 25.39 \\
\hline 4 & Pusian & 28.68 & 36.67 & 18.50 & 55.66 & 20.02 & 35.23 & 27.97 \\
\hline 5 & Toraut & 48.80 & 32.16 & 45.82 & 37.53 & 112.93 & 39.75 & 31.40 \\
\hline 6 & Konarom & 13.81 & 17.42 & 10.46 & 12.52 & 15.07 & 26.26 & 14.54 \\
\hline 7 & Andigile Buko & 11.09 & 16.95 & 8.76 & 14.80 & 5.88 & 4.77 & 5.99 \\
\hline 8 & Bolangitan - Paku & 31.42 & 21.50 & 22.86 & 20.69 & 20.69 & 38.81 & 30.02 \\
\hline 9 & Sangkub - Huntuk & 2.21 & 2.89 & 2.51 & 4.45 & 8.84 & 4.38 & 3.00 \\
\hline 10 & Bintauna Pantai & 9.89 & 7.79 & 12.53 & 16.70 & 13.78 & 13.20 & 11.14 \\
\hline 11 & Sangkub - Pangkusa & 33.18 & 21.62 & 39.88 & 62.89 & 44.40 & 37.06 & 25.82 \\
\hline 12 & Ayong Bumbung & 23.32 & 16.15 & 17.69 & 26.72 & 17.15 & 25.65 & 19.01 \\
\hline 13 & Nonapan - Wineru & 8.50 & 5.13 & 8.32 & 8.69 & 6.74 & 11.70 & 8.78 \\
\hline 14 & Lolak - Solog & 11.07 & 12.27 & 11.12 & 17.15 & 11.02 & 23.88 & 19.60 \\
\hline 15 & Moayat & 28.13 & 23.50 & 10.60 & 14.74 & 18.38 & 14.33 & 14.30 \\
\hline 16 & Nuangan - Lanut & 31.37 & 36.13 & 33.57 & 33.31 & 29.70 & 21.72 & 31.28 \\
\hline 17 & Buyat - Buyat & 12.60 & 12.03 & 12.07 & 11.08 & 8.61 & 13.22 & 9.05 \\
\hline 18 & Doloduo I & 9.31 & 1.67 & 6.37 & 4.47 & 6.84 & 3.53 & 4.62 \\
\hline 19 & Sangkub & 2.17 & 1.92 & 1.57 & 3.87 & 2.32 & 2.48 & 0.80 \\
\hline \multirow{2}{*}{\multicolumn{2}{|c|}{ Rerata }} & 379.31 & 296.45 & 331.43 & 463.34 & 437.71 & 385.15 & 335.43 \\
\hline & & \multicolumn{7}{|c|}{375.54} \\
\hline & Standar Deviasi & \multicolumn{7}{|c|}{59.85} \\
\hline & CV & \multicolumn{7}{|c|}{0.16} \\
\hline
\end{tabular}


Berdasarkan nilai standar deviasi dan rerata hujan didapatkan nilai koefisien variansi sebesar 0.16 .

Dari beberapa analisa di atas didapatkan beberapa nilai sebagai berikut yang akan digunakan sebagai dasar penentuan jarak ideal antar stasiun.
A

$\mathrm{r}(0)$

$\mathrm{d}(0)$

Standart Deviasi

Rerata

CV
$=7,448.99 \quad \mathrm{~km}^{2}$

$=0.62$

$=243.90$

$=59.85$

$=375.54$

$=0.16$

Hubungan antara Z1, Z2, dan L, dapat dilihat pada grafik berikut ini:

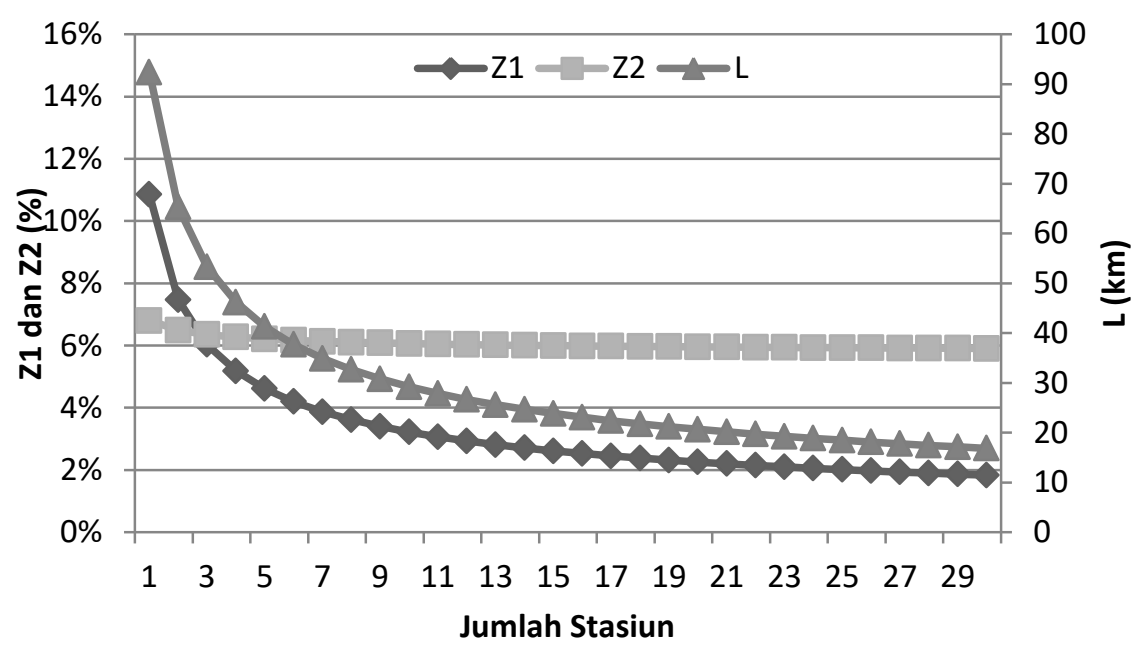

Gambar 5. Grafik Z1, Z2 dan L

Tabel 8. Perhitungan Tingkat Kesalahan dan Jarak Segitiga Kagan

\begin{tabular}{|c|c|c|c|}
\hline $\mathrm{N}$ & Z1 & Z2 & $\mathrm{L}$ \\
\hline 10 & $3.22 \%$ & $6.06 \%$ & 29.20 \\
\hline 11 & $3.06 \%$ & $6.04 \%$ & 27.84 \\
\hline 12 & $2.93 \%$ & $6.03 \%$ & 26.66 \\
\hline 13 & $2.81 \%$ & $6.02 \%$ & 25.61 \\
\hline 14 & $2.71 \%$ & $6.01 \%$ & 24.68 \\
\hline 15 & $2.61 \%$ & $5.99 \%$ & 23.84 \\
\hline 16 & $2.53 \%$ & $5.99 \%$ & 23.09 \\
\hline 17 & $2.45 \%$ & $5.98 \%$ & 22.40 \\
\hline 18 & $2.38 \%$ & $5.97 \%$ & 21.77 \\
\hline 19 & $2.31 \%$ & $5.96 \%$ & 21.19 \\
\hline 20 & $2.25 \%$ & $5.95 \%$ & 20.65 \\
\hline 21 & $2.20 \%$ & $5.95 \%$ & 20.15 \\
\hline 22 & $2.15 \%$ & $5.94 \%$ & 19.69 \\
\hline 23 & $2.10 \%$ & $5.94 \%$ & 19.26 \\
\hline 24 & $2.05 \%$ & $5.93 \%$ & 18.85 \\
\hline 25 & $2.01 \%$ & $5.93 \%$ & 18.47 \\
\hline 26 & $1.97 \%$ & $5.92 \%$ & 18.11 \\
\hline 27 & $1.93 \%$ & $5.92 \%$ & 17.77 \\
\hline 28 & $1.90 \%$ & $5.91 \%$ & 17.45 \\
\hline
\end{tabular}

\begin{tabular}{cccc}
\hline $\mathrm{N}$ & $\mathrm{Z} 1$ & $\mathrm{Z} 2$ & $\mathrm{~L}$ \\
\hline 29 & $1.87 \%$ & $5.91 \%$ & 17.15 \\
$\mathbf{3 0}$ & $\mathbf{1 . 8 3} \%$ & $\mathbf{5 . 9 1 \%}$ & $\mathbf{1 6 . 8 6}$
\end{tabular}

Berdasarkan uraian tersebut maka diperlukan penambahan pos baru sebanyak 19 buah. Namun jumlah tersebut masih harus dievaluasi terhadap Isohyet dan tata guna lahan WS Dumoga Sangkub.

Tabel 9. Pos Hujan Susuai Metode Kagan

\begin{tabular}{c|l|c|c|}
\hline \multirow{2}{*}{ No. } & \multicolumn{2}{|c|}{ Stasiun } & \multicolumn{2}{|c|}{ Koordinat } \\
\cline { 3 - 4 } & & \multicolumn{1}{|c|}{ X } & Y \\
\hline 1 & Matayangan & $123^{\circ} 57^{\prime} 43.50^{\prime \prime} \mathrm{E}$ & $0^{\circ} 27^{\prime} 53.16^{\prime \prime} \mathrm{N}$ \\
\hline 2 & Toraut & $123^{\circ} 54^{\prime} 21.84^{\prime \prime} \mathrm{E}$ & $0^{\circ} 33^{\prime} 51.42^{\prime \prime} \mathrm{N}$ \\
\hline 3 & Konarom & $124^{\circ} 0^{\prime} 57.12^{\prime \prime} \mathrm{E}$ & $0^{\circ} 35^{\prime} 12.24^{\prime \prime} \mathrm{N}$ \\
\hline 4 & Andigile Buko & $123^{\circ} 8^{\prime} 2.10^{\prime \prime} \mathrm{E}$ & $0^{\circ} 53^{\prime} 14.22^{\prime \prime} \mathrm{N}$ \\
\hline 5 & Bolangitan - Paku & $123^{\circ} 19^{\prime} 47.34^{\prime \prime} \mathrm{E}$ & $0^{\circ} 51^{\prime} 18.00^{\prime \prime} \mathrm{N}$ \\
\hline 6 & Bintauna Pantai & $123^{\circ} 34^{\prime} 52.98^{\prime \prime} \mathrm{E}$ & $0^{\circ} 52^{\prime} 44.10^{\prime \prime} \mathrm{N}$ \\
\hline 7 & Nonapan - Wineru & $124^{\circ} 15^{\prime} 49.86^{\prime \prime} \mathrm{E}$ & $0^{\circ} 57^{\prime} 35.22^{\prime \prime} \mathrm{N}$ \\
\hline 8 & Lolak - Solog & $124^{\circ} 5^{\prime} 55.68^{\prime \prime} \mathrm{E}$ & $0^{\circ} 53^{\prime} 12.36^{\prime \prime} \mathrm{N}$ \\
\hline 9 & Buyat - Buyat & $124^{\circ} 41^{\prime} 43.44^{\prime \prime} \mathrm{E}$ & $0^{\circ} 51^{\prime} 24.96^{\prime \prime} \mathrm{N}$ \\
\hline
\end{tabular}




\subsection{Penyusunan Peta Isohyet}

Pada studi ini Pembuatan peta dilakukan dengan bantuan software arcgis yaitu dengan metode IDW (interpolates distance weighted) sebagai metode untuk interpolasi kontur Isohyet. Data hujan yang digunakan dalam pembuatan Isohyet adalah data rerata tahunan dari setiap pos hujan. Berikut ini adalah data dan hasil pembuatan Isohyet WS Dumoga Sangkub.

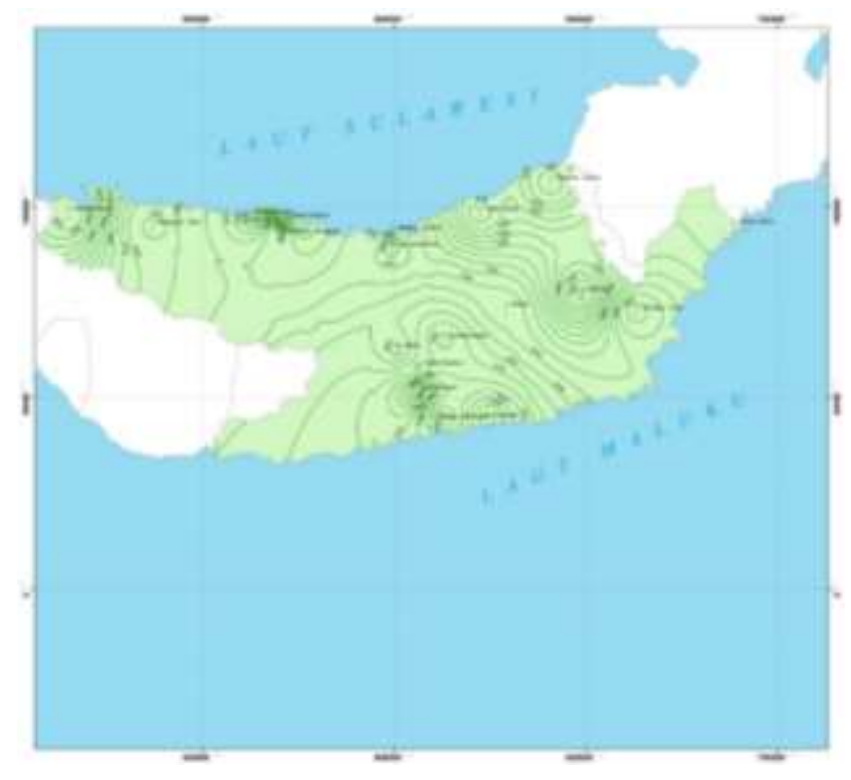

Gambar 6. Peta Isohyet WS Dumoga Sangkub

\subsection{Rekomendasi Pos Hujan}

Rekomendasi pos hujan dilakukan berdasarkan beberapa hal yang menjadi pertimbangan dalam memberikan rekomendasi pos hidrologi :

1. Analisa Metode Kagan

2. MasterPlan WS Dumoga Sangkub

Pada masterplan WS Dumoga Sangkub telah dilakukan perencanaan secara umum untuk pengembangan sumber daya air. Oleh karena itu pada penyusunan rekomendasi pos hidrologi perlu dikaji pula letak pos terhadap rencana pengembangan SDA. Sebagai contoh terdapat rencana pembangunan daerah irigasi, maka dapat dipastikan lokasi tersebut juga memerlukan pos hujan atau klimatologi.

3. Keterwakilan DAS

Metode Kagan disusun berdasarkan jarak setiap pos hujan. Sehingga akan muncul kemungkinan sebuah das tidak memiliki pos hujan hasil metode kagan. Oleh karena itu pada rekomendasi ini juga dipertimbangkan masalah keterwakilan DAS.

4. Analisa tata guna lahan

Berdasarkan hasil analisa metode Kagan, didapatkan beberapa lokasi rekomendasi. Namun pada lokasi tersebut belum tentu terdapat access road maupun pemukiman penduduk (sebagai penjaga pos). Sehingga aspek kemudahan perlu dijadikan pertimbangan dalam penentuan lokasi pos hidrologi.

Tabel 8 menampilkan data rekomendasi lokasi pos hujan. Untuk peta ditampilkan pada Gambar 7. Sehingga total stasiun yang nantinya ada di WS Dumoga Sangkub adalah 30 buah, dengan perincian 19 pos lama dan 11 pos baru. 


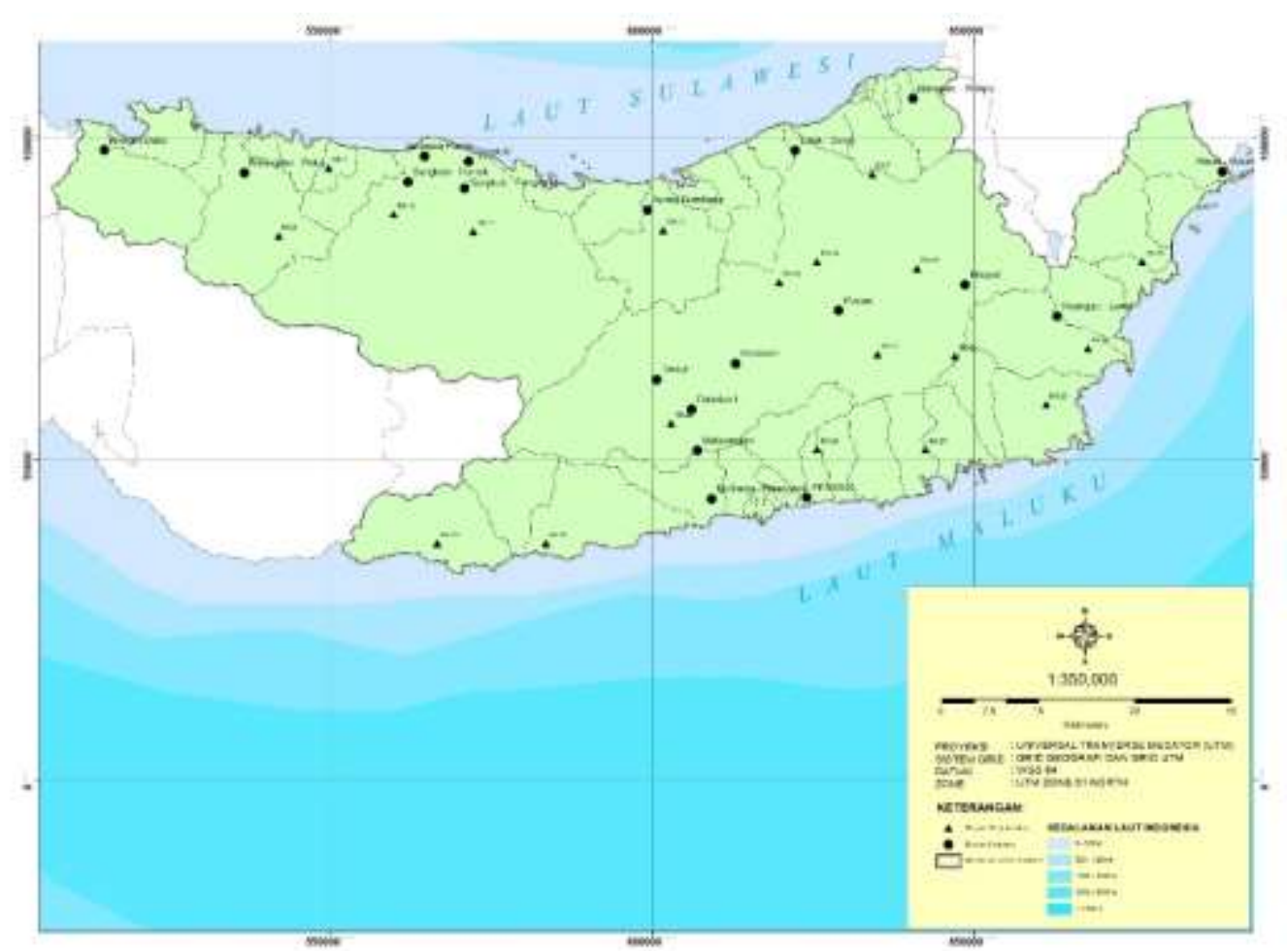

Gambar 7. letak stasiun hujan hasil analisa Kagan Rodda

Tabel 10. Stasiun hujan hasil analisa Kagan Rodda

\begin{tabular}{|c|c|c|c|c|}
\hline \multirow{2}{*}{ No } & \multirow{2}{*}{ Nama Pos } & \multirow{2}{*}{ Status } & \multicolumn{2}{|c|}{ Koordinat } \\
\hline & & & $\mathbf{X}$ & $\mathbf{Y}$ \\
\hline 1 & Doloduo I & Pos Klimatologi Eksisting & $123^{\circ} 57^{\prime} 16.86^{\prime \prime} \mathrm{E}$ & $0^{\circ} 31^{\prime} 20.34^{\prime \prime} \mathrm{N}$ \\
\hline 2 & Sangkub & Pos Klimatologi Eksisting & $123^{\circ} 38^{\prime} 35.70^{\prime \prime} \mathrm{E}$ & $0^{\circ} 52^{\prime} 18.12^{\prime \prime} \mathrm{N}$ \\
\hline 3 & RK-1 - Nonapan Wineru & Pos Kagan sesuai dengan pos eksisting & $124^{\circ} 15^{\prime} 49.86^{\prime \prime} \mathrm{E}$ & $0^{\circ} 57^{\prime} 35.22^{\prime \prime} \mathrm{N}$ \\
\hline 4 & RK-2 - Andigile Buko & Pos Kagan sesuai dengan pos eksisting & $123^{\circ} 8^{\prime} 2.10^{\prime \prime} \mathrm{E}$ & $0^{\circ} 53^{\prime} 14.22^{\prime \prime} \mathrm{N}$ \\
\hline 5 & RK-3 - Bolangitang Paku & Pos Kagan sesuai dengan pos eksisting & $123^{\circ} 19^{\prime} 47.34^{\prime \prime} \mathrm{E}$ & $0^{\circ} 51^{\prime} 18.00^{\prime \prime} \mathrm{N}$ \\
\hline 6 & RK-5 - Bintauna Pantai & Pos Kagan sesuai dengan pos eksisting & $123^{\circ} 34^{\prime} 52.98^{\prime \prime} \mathrm{E}$ & $0^{\circ} 52^{\prime} 44.10^{\prime \prime} \mathrm{N}$ \\
\hline 7 & RK-6 - Lolak Solog & Pos Kagan sesuai dengan pos eksisting & $124^{\circ} 5^{\prime} 55.68^{\prime \prime} \mathrm{E}$ & $0^{\circ} 53^{\prime} 12.36^{\prime \prime} \mathrm{N}$ \\
\hline 8 & RK-8 - Buyat Buyat & Pos Kagan sesuai dengan pos eksisting & $124^{\circ} 41^{\prime} 43.44^{\prime \prime} \mathrm{E}$ & $0^{\circ} 51^{\prime} 24.96 " \mathrm{~N}$ \\
\hline 9 & RK-19 - Toraut & Pos Kagan sesuai dengan pos eksisting & $123^{\circ} 54^{\prime} 21.84^{\prime \prime} \mathrm{E}$ & $0^{\circ} 33^{\prime} 51.42^{\prime \prime} \mathrm{N}$ \\
\hline 10 & RK-20 - Konarom Barat & Pos Kagan sesuai dengan pos eksisting & $124^{\circ} 0^{\prime} 57.12^{\prime \prime} \mathrm{E}$ & $0^{\circ} 35^{\prime} 12.24 " \mathrm{~N}$ \\
\hline 11 & RK-25 - Matayangan & Pos Kagan sesuai dengan pos eksisting & $123^{\circ} 57^{\prime} 43.50^{\prime \prime} \mathrm{E}$ & $0^{\circ} 27^{\prime} 53.16^{\prime \prime} \mathrm{N}$ \\
\hline 12 & RK-4 & Pos Rekomendasi Kagan dan sesuai dengan Isohyet & $123^{\circ} 26^{\prime} 50.88^{\prime \prime} \mathrm{E}$ & $0^{\circ} 51^{\prime} 42.72^{\prime \prime} \mathrm{N}$ \\
\hline 13 & RK-7 & Pos Rekomendasi Kagan dan sesuai dengan Isohyet & $124^{\circ} 12^{\prime} 23.32^{\prime \prime} \mathrm{E}$ & $0^{\circ} 51^{\prime} 9.57^{\prime \prime} \mathrm{N}$ \\
\hline 14 & RK-9 & Pos Rekomendasi Kagan dan sesuai dengan Isohyet & $124^{\circ} 12^{\prime} 23.32^{\prime \prime} \mathrm{E}$ & $0^{\circ} 51^{\prime} 9.57^{\prime \prime} \mathrm{N}$ \\
\hline 15 & RK-10 & Pos Rekomendasi Kagan dan sesuai dengan Isohyet & $123^{\circ} 22^{\prime} 38.64^{\prime \prime} \mathrm{E}$ & $0^{\circ} 45^{\prime} 57.40^{\prime \prime} \mathrm{N}$ \\
\hline 16 & RK-11 & Pos Rekomendasi Kagan dan sesuai dengan Isohyet & $123^{\circ} 32^{\prime} 16.68^{\prime \prime} \mathrm{E}$ & $0^{\circ} 47^{\prime} 46.99^{\prime \prime} \mathrm{N}$ \\
\hline 17 & RK-13 & Pos Rekomendasi Kagan dan sesuai dengan Isohyet & $123^{\circ} 38^{\prime} 58.24^{\prime \prime} \mathrm{E}$ & $0^{\circ} 46^{\prime} 19.54 " \mathrm{~N}$ \\
\hline 18 & RK-14 & Pos Rekomendasi Kagan dan sesuai dengan Isohyet & $124^{\circ} 4^{\prime} 34.57^{\prime \prime} \mathrm{E}$ & $0^{\circ} 42^{\prime} 1.50^{\prime \prime} \mathrm{N}$ \\
\hline 19 & RK-16 & Pos Rekomendasi Kagan dan sesuai dengan Isohyet & $124^{\circ} 77^{\prime} 45.35^{\prime \prime} \mathrm{E}$ & $0^{\circ} 43^{\prime} 46.73^{\prime \prime} \mathrm{N}$ \\
\hline 20 & RK-21 & Pos Rekomendasi Kagan dan sesuai dengan Isohyet & $124^{\circ} 35^{\prime} 1.39^{\prime \prime} \mathrm{E}$ & $0^{\circ} 43^{\prime} 46.24 " \mathrm{~N}$ \\
\hline 21 & RK-22 & Pos Rekomendasi Kagan dan sesuai dengan Isohyet & $124^{\circ} 12^{\prime} 50.48^{\prime \prime} \mathrm{E}$ & $0^{\circ} 35^{\prime} 58.06^{\prime \prime} \mathrm{N}$ \\
\hline 22 & RK-26 & Pos Rekomendasi Kagan dan sesuai dengan Isohyet & $124^{\circ} 19^{\prime} 18.21^{\prime \prime} \mathrm{E}$ & $0^{\circ} 35^{\prime} 47.65^{\prime \prime} \mathrm{N}$ \\
\hline 23 & RK-27 & Pos Rekomendasi Kagan dan sesuai dengan Isohyet & $124^{\circ} 7^{\prime} 45.15^{\prime \prime} \mathrm{E}$ & $0^{\circ} 27^{\prime} 55.79^{\prime \prime} \mathrm{N}$ \\
\hline 24 & RK-29 & Pos Rekomendasi Kagan dan sesuai dengan Isohyet & $124^{\circ} 16^{\prime} 50.51^{\prime \prime} \mathrm{E}$ & $0^{\circ} 27^{\prime} 55.70^{\prime \prime} \mathrm{N}$ \\
\hline 25 & RK-30 & Pos Rekomendasi Kagan dan sesuai dengan Isohyet & $123^{\circ} 35^{\prime} 56.17^{\prime \prime} \mathrm{E}$ & $0^{\circ} 20^{\prime} 0.49 " \mathrm{~N}$ \\
\hline 26 & RK-12 & Pos rekomendasi yang letaknya disesuaikan dengan tata guna lahan & $123^{\circ} 45^{\prime} 1.60^{\prime \prime} \mathrm{E}$ & $0^{\circ} 20^{\prime} 0.45^{\prime \prime} \mathrm{N}$ \\
\hline 27 & RK-15 & Pos rekomendasi yang letaknya disesuaikan dengan tata guna lahan & $124^{\circ} 16^{\prime} 9.15^{\prime \prime} \mathrm{E}$ & $0^{\circ} 43^{\prime} 11.85^{\prime \prime} \mathrm{N}$ \\
\hline 28 & RK-23 & Pos rekomendasi yang letaknya disesuaikan dengan tata guna lahan & $124^{\circ} 30^{\prime} 27.40^{\prime \prime} \mathrm{E}$ & $0^{\circ} 36^{\prime} 27.78^{\prime \prime} \mathrm{N}$ \\
\hline 29 & RK-24 & Pos rekomendasi yang letaknya disesuaikan dengan tata guna lahan & $123^{\circ} 55^{\prime} 31.62^{\prime \prime} \mathrm{E}$ & $0^{\circ} 30^{\prime} 7.64 " \mathrm{~N}$ \\
\hline 30 & RK-28 & Pos rekomendasi yang letaknya disesuaikan dengan tata guna lahan & $124^{\circ} 26^{\prime} 57.08^{\prime \prime} \mathrm{E}$ & $0^{\circ} 31^{\prime} 42.83^{\prime \prime} \mathrm{N}$ \\
\hline
\end{tabular}




\section{DAFTAR PUSTAKA}

[1] H. Mulya, "Studi Rasionalisasi Jaringan Hidrologi Pulau Seram Provinsi Maluku," Media Komun. Tek. Sipil, vol. 20, no. 1, pp. 71-82, 2015, doi: 10.14710/mkts.v20i1.9248.

[2] L. Ranesa, "Analisis Rasionalisasi Jaringan Pos Hujan untuk Kalibrasi Hidrograf pada DAS Babak Kabupaten Lombok Tengah," J. Pengair., vol. 6, p. 46, 2015.

[3] S. Fathoni, "Analisis Efektivitas Kerapatan Jaringan Pos Stasiun Hujan di DAS Kedungsoko dengan Menggunakan Jaringan Saraf Tiruan (Artificial Neural Network)," J. Pengair., vol. 7, p. 129, 2016.

[4] WMO, Guide to Hydrological Practices. Volume I: Hydrology-From Measurement to Hydrological Information, vol. I, no. 168. 2008.

[5] B. Sri Harto, Hidrologi Teknik. 1993.

[6] Z. R. Alfirman, "Rasionalisasi Kerapatan Pos Hujan Menggunakan Metode Kagan-Rodda di Sub DAS Lesti," J. Tek. Sipil, vol. 8, no. 2, pp. 153-164, 2019.

[7] Purwanto, "Pengisian Data Hujan yang Hilang dengan Metode Arima," J. UMY, 2016.

[8] E. Prawati, "Jaringan Stasiun Hujan Ditinjau dari Topografi pada DAS Widas Kabupaten Nganjuk - Jawa Timur," vol. 6, no. 1, pp. 86-98, 2016.

[9] A. Oktaviansyah, "Analisa Rasionalisasi Jaringan Pos Hidrologi Padawilayah Sungai/DAS Sampea," J. Sist., vol. 13, p. 23, 2017.

[10] Sosrodarsono Suyono, Hidrologi Untuk Pengairan. 1999. 